\title{
$\alpha$-Pinene, Limonene, and Cyclohexene Secondary Organic Aerosol Hygroscopicity and Oxidation Level as a Function of Volatility
}

\author{
Kerrigan P. Cain ${ }^{1}$, Aikaterini Liangou ${ }^{2}$, Michael L. Davidson ${ }^{1}$, \\ Spyros N. Pandis ${ }^{1,2,3^{*}}$ \\ ${ }^{1}$ Department of Chemical Engineering, Carnegie Mellon University, Pittsburgh, USA \\ ${ }^{2}$ Department of Chemical Engineering, University of Patras, Patras, Greece \\ ${ }^{3}$ Institute of Chemical Engineering Sciences, ICE-HT, Patras, Greece
}

\section{ABSTRACT}

The hygroscopicity and oxidation level of secondary organic aerosol (SOA) produced in an atmospheric simulation chamber were measured as a function of volatility. The experimental setup combines thermodenuding, isothermal dilution, aerosol mass spectroscopy, and size-resolved cloud condensation nuclei measurements to separate the SOA by volatility and then measure its physical (hygroscopicity via the hygroscopicity parameter, $\kappa$ ) and chemical (oxidation level via the oxygen-to-carbon ratio, $\mathrm{O}: \mathrm{C}$ ) properties. The technique was applied to SOA from the ozonolysis of $\alpha$-pinene, limonene, and cyclohexene. The O:C and $\kappa$ of the $\alpha$-pinene ozonolysis SOA decreased as volatility decreased. The semi-volatile and the low volatility organic compounds produced during limonene ozonolysis have similar $\mathrm{O}: \mathrm{C}$ and $\kappa$ values, but the corresponding extremely low volatility organic compounds have significantly lower oxygen content and hygroscopicity. The average O:C of the cyclohexene ozonolysis SOA increased, but the average $\kappa$ decreased as volatility decreased. These results suggest that some organic aerosol (OA) systems have a more complex relationship between hygroscopicity, oxidation level, and volatility than originally thought. The two-dimensional volatility basis set framework can help in integrating these results and providing explanations of the measured hygroscopicity. Use of this technique with different OA systems, both laboratory and ambient, can supply parameters that can be incorporated in atmospheric chemical transport models.

Keywords: Cloud condensation nuclei, Isothermal dilution, Organic compounds, Thermodenuder

Received: August 9, 2020

Revised: October 19, 2020

Accepted: November 22, 2020

${ }^{*}$ Corresponding Author:

spyros@andrew.cmu.edu

\section{Publisher:}

Taiwan Association for Aerosol Research

ISSN: $1680-8584$ print

ISSN: 2071-1409 online

CC) Copyright: The Author(s).

This is an open access article distributed under the terms of the Creative Commons Attribution License (CC BY 4.0), which permits unrestricted use, distribution, and reproduction in any medium, provided the original author and source are cited.

\section{INTRODUCTION}

Organic aerosol (OA), a potentially large fraction of particulate matter depending on location (Zhang et al., 2007), is a complex mixture of organic compounds that continuously evolve in the atmosphere. OA can be emitted directly in the particulate-phase, known as primary OA (POA), or produced by the condensation of compounds formed from the oxidation of vapor-phase precursors, known as secondary OA (SOA), (Kanakidou et al., 2005; Hallquist et al., 2009). The evolution of OA in the atmosphere is still poorly understood, largely due to the thousands of compounds that comprise it and the difficulty of elucidating their physical and chemical properties (Jimenez et al., 2009; Heald et al., 2010; Kroll et al., 2011; Ditto et al., 2018).

As OA progresses through time in the atmosphere, its composition changes due to evaporation/condensation, addition of fresh emissions, and particulate and vapor-phase reactions (Kroll et al., 2011; Donahue et al., 2013). Three crucial properties that affect the evolution and atmospheric fate of OA are hygroscopicity, oxidation level, and volatility. Hygroscopicity, often represented with the hygroscopicity parameter, $\kappa$ (Petters and Kreidenweis, 2007), is a measure of a compound's ability to absorb water. Oxidation level, sometimes expressed as the oxygen-tocarbon ratio, O:C, or, more accurately, the average carbon oxidation state, OSc (Kroll et al., 2011), 
is a surrogate for compositional changes of OA as it ages in the atmosphere. Volatility determines, to a large extent, a compound's partitioning between the particulate and vapor-phases. The onedimensional volatility basis set (1D-VBS) was proposed as a framework to describe the volatility distribution of OA over several orders of magnitude (Donahue et al., 2006). This framework has been extended to include the oxidation level in the two-dimensional volatility basis set (2D-VBS) to better capture OA behavior in the atmosphere (Donahue et al., 2011). Both changes in volatility and oxidation level can be followed by the 2D-VBS thus reflecting more accurately processes occurring in the atmosphere (e.g., reactions, fragmentation, oligomerization).

Many previous studies have attempted to relate two of these three properties for ambient and laboratory OA (e.g., Meyer et al., 2009; Massoli et al., 2010; Donahue et al., 2011; Frosch et al., 2011; Lambe et al., 2011; Rickards et al., 2013). A growing number of studies have attempted to relate all three properties, but the results are often inconclusive or a clear relationship between the studies cannot be established (Jimenez et al., 2009; Poulain et al., 2010; Kuwata et al., 2011; Tritscher et al., 2011; Hong et al., 2014; Cerully et al., 2015; Hildebrandt Ruiz et al., 2015; Cain and Pandis, 2017; Alroe et al., 2018; Kostenidou et al., 2018). For example, Jimenez et al. (2009) proposed that, in general, the hygroscopicity and oxidation level of OA increase as volatility decreases. On the other hand, Cerully et al. (2015) observed similar oxidation levels for ambient OA components with significantly different volatility, but the hygroscopicity of the OA decreased with decreasing volatility. Nakao (2017) theoretically investigated the hygroscopicity and solubility of OA in the 2D-VBS. This study estimated lines of constant $\kappa$ in the 2D-VBS, which provided a plausible explanation for why the dependence of $\kappa$ on $\mathrm{O}: \mathrm{C}$ and volatility should not be simple. These examples and the results from several other studies (Poulain et al., 2010; Kuwata et al., 2011; Tritscher et al., 2011; Hong et al., 2014; Hildebrandt Ruiz et al., 2015; Cain and Pandis, 2017; Alroe et al., 2018; Kostenidou et al., 2018) indicate that the relationship between these three properties is complex and not well understood.

Cain and Pandis (2017) developed an experimental and analysis technique that quantitatively relates hygroscopicity and oxidation level to volatility. They utilized a thermodenuder (TD), a heated tube followed by a cooling section with activated carbon to absorb vapor-phase compounds, to evaporate SOA and characterize the remaining fraction's hygroscopicity and oxidation level. With this technique, the authors concluded that the least volatile components of $\alpha$-pinene ozonolysis SOA had low O:C and $\kappa$ values. However, the use of a TD as the only tool to probe the OA volatility introduced significant uncertainty in the estimated volatility distributions. In the present study, we use the improved approach from Cain et al. (2020) that combines isothermal dilution and TD measurements to characterize the volatility distribution.

The composition and properties of the SOA resulting from the $\alpha$-pinene and limonene ozonolysis have been studied extensively (e.g., Gao et al., 2004; Huff Hartz et al., 2005; Leungsakul et al., 2005; Varutbangkul et al., 2006; Heaton et al., 2007; Saathoff et al., 2009; Chen and Hopke, 2010; Kundu et al., 2012; Watne et al., 2017; Witkowski and Gierczak, 2017; Yuan et al., 2017). Limonene has two double bonds (one endocyclic and one exocyclic), making it more reactive towards ozone and forming SOA with higher yields and O:C values than $\alpha$-pinene ozonolysis SOA (Leungsakul et al., 2005; Heaton et al., 2007; Saathoff et al., 2009; Chen and Hopke, 2010). However, $\alpha$-pinene and limonene ozonolysis SOA have similar hygroscopic properties (Huff Hartz et al., 2005; Varutbangkul et al., 2006; Yuan et al., 2017). SOA from the ozonolysis of cyclohexene has been studied primarily to understand the cycloalkene ozonolysis mechanism and reaction products (Kalberer et al., 2000; Gao et al., 2004; Keywood et al., 2004a, b; Bahreini et al., 2005; Rissanen et al., 2014; Hyttinen et al., 2017; Hansel et al., 2018), but a few studies have examined its hygroscopic properties (Varutbangkul et al., 2006; Warren et al., 2009). Both Varutbangkul et al. (2006) and Warren et al. (2009) used subsaturated conditions and observed diameter growth factors for cyclohexene ozonolysis SOA that were significantly higher than the growth factors of monoterpene ozonolysis SOA. The present study is the first that examines the hygroscopic behavior of cyclohexene ozonolysis SOA under supersaturated conditions.

In this work, we extend the experimental technique of Cain and Pandis (2017) by adding isothermal dilution to the set of measurements. Cain et al. (2020) showed that this addition can better constrain the SOA volatility distribution. The resulting method is then applied to SOA from the ozonolysis of $\alpha$-pinene, limonene, and cyclohexene to examine the relationship between hygroscopicity, oxidation level, and volatility in these systems. 


\subsection{Experimental Setup}

The experimental setup combines the parallel TD and isothermal dilution measurements from Cain et al. (2020) with the hygroscopicity and oxidation level measurements from Cain and Pandis (2017). A schematic of the experimental setup can be seen in Fig. 1. Full details on the experimental setups can be found in the respective publications. Briefly, at the start of each experiment, isotopically-labelled butanol (n-butanol-d9, Cambridge Isotope Laboratories, 98\%) was injected into a $10 \mathrm{~m}^{3}$ Teflon main chamber as a dilution tracer. Following the tracer injection, either $\alpha$ pinene (Sigma-Aldrich, $\geq 99 \%$ ), limonene (Sigma-Aldrich, Analytical Standard), or cyclohexene (Sigma-Aldrich, 99+\%) was injected into the main chamber through a heated septum injector. Once the precursor concentration stabilized, ozone was generated by an ozone generator (AZCO, model HTU-500ACPS) and injected into the main chamber to begin the ozonolysis reaction. Once the reaction was complete in the main chamber, aerosol was isothermally diluted to a $2.5 \mathrm{~m}^{3}$ Teflon chamber and measurements were alternated between chambers by three-way valves. In order to minimize the potential for continued reactions occurring in the dilution chamber, the initial ozonolysis reaction proceeded in the main chamber for a minimum of $1 \mathrm{~h}$ before the aerosol was transferred to the dilution chamber.

Aerosol from the main chamber was characterized by a TD followed by an Aerodyne highresolution time-of-flight aerosol mass spectrometer (HR-ToF-AMS, hereafter AMS) and a differential mobility analyzer (DMA, TSI, model 3081) coupled with a condensation particle counter (CPC, TSI, model 3072) and a cloud condensation nuclei (CCN) counter (CCNC, Droplet Measurement Technologies) to allow for scanning mobility CCN analysis (SMCA, Moore et al., 2010). Also sampling from the main chamber were a proton transfer reaction mass spectrometer (PTR-MS, Ionicon Analytic) to monitor volatile organic compound (VOC) concentrations, an ozone monitor (Dasibi Environmental Corporation, model 1008-PC) to measure ozone concentrations, and a scanning mobility particle sizer (SMPS, TSI, DMA model 3081, CPC model 3075) to monitor particle size distributions and concentrations. Aerosol from the dilution chamber was characterized by the same instruments, except for the TD. The centerline residence time in the heated section of the TD at $25^{\circ} \mathrm{C}$ was $23 \mathrm{~s}$. Table 1 summarizes the experimental conditions examined in this study.

\subsection{Data Analysis}

The data analysis in this study utilizes the techniques described in Cain and Pandis (2017) and Cain et al. (2020). Briefly, hygroscopicity was quantified with the hygroscopicity parameter, $\kappa$,

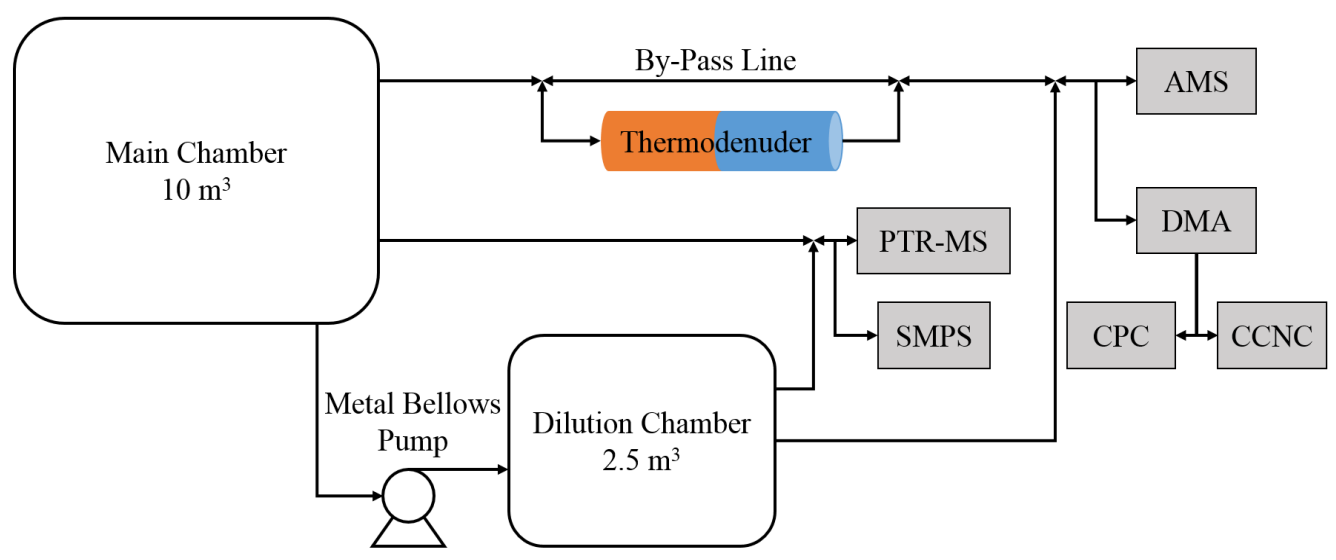

Fig. 1. The experimental setup used in this study. Particles from the main chamber were characterized with a TD followed by an AMS and a DMA coupled with a CPC and CCNC. Particles were transferred from the main chamber to the dilution chamber via a metal bellows pump and then particles from the dilution chamber were sampled by the same equipment via a three-way valve. Also connected to both chambers via a three-way valve were a PTR-MS, ozone monitor, and SMPS. 
Table 1. Description of the experimental conditions used in this study.

\begin{tabular}{|c|c|c|c|c|c|c|}
\hline Exp. & Precursor & VOC (ppb) & Ozone (ppb) & Main Chamber SOA ${ }^{a}\left(\mu \mathrm{g} \mathrm{m}^{-3}\right)$ & $\operatorname{CCNC~SS}^{\mathrm{b}}(\%)$ & Dilution Ratio \\
\hline AP1 & $\alpha$-Pinene & 50 & $>500^{c}$ & 90 & 0.35 & $25.7 \pm 1.0$ \\
\hline AP2 & $\alpha$-Pinene & 75 & $>500^{c}$ & 125 & 0.33 & $25.3 \pm 1.1$ \\
\hline AP3 & $\alpha$-Pinene & 100 & $>500^{c}$ & 195 & 0.31 & $14.7 \pm 0.8$ \\
\hline AP4 & $\alpha$-Pinene & 125 & $>500^{c}$ & 255 & 0.31 & $21.2 \pm 1.2$ \\
\hline LM1 & Limonene & 60 & 875 & 240 & 0.32 & $25.2 \pm 1.5$ \\
\hline LM2 & Limonene & 60 & 875 & 230 & 0.31 & $20.9 \pm 1.4$ \\
\hline LM3 & Limonene & 75 & 900 & 295 & 0.30 & $19.5 \pm 0.7$ \\
\hline $\mathrm{CH} 1$ & Cyclohexene & 150 & 600 & 45 & 0.09 & $9.1 \pm 0.6$ \\
\hline $\mathrm{CH} 2$ & Cyclohexene & 150 & 700 & 65 & 0.09 & $8.9 \pm 0.6$ \\
\hline $\mathrm{CH} 3$ & Cyclohexene & 175 & 750 & 80 & 0.08 & $11.2 \pm 0.6$ \\
\hline $\mathrm{CH} 4$ & Cyclohexene & 175 & 650 & 85 & 0.09 & $9.1 \pm 0.6$ \\
\hline $\mathrm{CH} 5$ & Cyclohexene & 200 & 650 & 105 & 0.08 & $8.2 \pm 0.5$ \\
\hline
\end{tabular}

${ }^{a}$ Maximum SOA mass calculated from the SMPS measurements assuming a density of $1.4 \mathrm{~g} \mathrm{~cm}^{-3}$.

${ }^{b}$ CCNC supersaturation was held constant during experiments to allow sufficient time for averaging.

${ }^{c}$ The exact value is uncertain due to problems with the ozone monitor.

and determined from activation diameters and water supersaturations from the CCNC (Petters and Kreidenweis, 2007). Oxidation level was quantified by the $O: C$ and determined from the AMS using the Canagaratna et al. (2015) method. Volatility distributions were estimated using a thermogram and areogram, which describe particle mass fraction remaining (MFR) as a function of TD temperature and dilution time respectively, and a mass transfer model (Riipenen et al., 2010; Karnezi et al., 2014). Full details on the volatility fitting process can be found in Cain et al. (2020). Thermograms were corrected for size and temperature dependent losses, as specified in Cain and Pandis (2017). Areograms were also corrected for size-dependent particle wall-losses and the uncertainty from this correction over time is propagated into the uncertainty of the areograms, as described in Cain et al. (2020). In this work, we used volatility bins for all of the SOA ranging from $10^{-5}$ to $10^{3} \mu \mathrm{g} \mathrm{m}^{-3}$. After the detailed 1-D VBS volatility distribution was estimated, we also grouped the results based on their effective saturation concentration, $C^{*}$, into four classes, intermediate volatility organic compounds (IVOCs, $C^{*} \geq 10^{3} \mu \mathrm{g} \mathrm{m}^{-3}$ ), semi-volatile organic compounds (SVOCs, $10^{0} \mu \mathrm{g} \mathrm{m}^{-3} \leq C^{*} \leq 10^{2} \mu \mathrm{g} \mathrm{m}^{-3}$ ), low volatility organic compounds (LVOCs, $10^{-3} \mu \mathrm{g} \mathrm{m}^{-3} \leq C^{*} \leq 10^{-1}$ $\mu \mathrm{g} \mathrm{m}^{-3}$ ), or extremely low volatility organic compounds (ELVOCs, $C^{*} \leq 10^{-4} \mu \mathrm{g} \mathrm{m}^{-3}$ ).

$\mathrm{O}: \mathrm{C}$ and $\kappa$ distributions as a function of volatility bin for each experiment were determined using the following equations adapted from Cain and Pandis (2017):

$$
\begin{aligned}
& {[\mathrm{O}: \mathrm{C}]_{j}=\sum_{i=1}^{n} x_{i, j}[\mathrm{O}: \mathrm{C}]_{i}} \\
& \kappa_{j}=\sum_{i=1}^{n} x_{i, j} \kappa_{i}
\end{aligned}
$$

where $[\mathrm{O}: \mathrm{C}]_{j}$ and $\kappa_{j}$ are the measured $\mathrm{O}: \mathrm{C}$ and $\kappa$ at a TD temperature or dilution residence time, $x_{i, j}$ is the SOA mass fraction in the $i^{\text {th }}$ volatility bin (e.g., $C^{*}=10^{-5} \mu \mathrm{g} \mathrm{m}^{-3}$ ) at the same temperature or dilution time, and $[\mathrm{O}: \mathrm{C}]_{i}$ and $\kappa_{i}$ are the unknown $\mathrm{O}: \mathrm{C}$ and $\kappa$ for the $i^{\text {th }}$ volatility bin.

These equations were used to generate a system of equations for both the $0: C$ and $\kappa$ values that can be solved separately. Due to the number of TD and dilution measurements, each experiment resulted in an overdetermined problem (i.e., more equations than unknown parameters). Therefore, we used a linear least squares approach to minimize the difference between the measured and predicted O:C and $\kappa$ values. Matlab's linear least squares solver, Isqlin, was used for this error minimization problem with a lower bound constraint of zero for both systems. For each SOA experiment, we averaged the $O: C$ and $\kappa$ values across the different volatility classes to reduce the uncertainty in the $\mathrm{O}: \mathrm{C}$ and $\kappa$ distributions. We then averaged these distributions over all experiments and used the standard deviation as a zeroth order metric for the uncertainty of our analysis. 


\section{RESULTS AND DISCUSSION}

\subsection{System Test with Ammonium Sulfate}

We tested our system with ammonium sulfate aerosol to ensure that this complex experimental setup was working properly (Cain and Pandis, 2017; Cain et al., 2020). For this test, we injected a $1 \mathrm{~g} \mathrm{~L}^{-1}$ solution of ammonium sulfate (Sigma-Aldrich, $\geq 99 \%$ ) into the main chamber using an atomizer (TSI, model 3075) followed by a silica gel dryer to produce dry particles. We then followed the experimental procedure to test the system. The thermogram, areogram, and activation diameter results for this experiment can be seen in Fig. S1. There was no evaporation in either the TD (below temperatures of $125^{\circ} \mathrm{C}$ ) or dilution chamber (after $5 \mathrm{~h}$ of dilution). In addition, the activation diameters at different TD temperatures and in the dilution chamber agreed with Köhler theory predictions using the surface tension of water at $25^{\circ} \mathrm{C}$. Therefore, we concluded that our system was operating properly.

\subsection{SOA Results}

The experimental procedure was applied to SOA from the ozonolysis of $\alpha$-pinene, limonene, and cyclohexene with the conditions specified in Table 1. All of the results can be found in the supplemental information with results of a few representative experiments discussed in more detail in the subsequent sections.

\section{$3.3 \alpha$-Pinene Ozonolysis SOA}

The thermogram and areogram, along with fits from the mass transfer model, for Experiment AP1 are shown in Fig. 2. There was $5 \%$ of the SOA remaining after passing through the TD at $150^{\circ} \mathrm{C}$, but only $12 \%$ of the SOA evaporated in the dilution chamber after being diluted by a factor of 25 for over $3 \mathrm{~h}$. The model reproduced the measurements well with only small deviations from the measured thermogram. The SOA in Experiment AP1 was comprised of, according to the model, 15\% ELVOCs, 59\% LVOCs, and 26\% SVOCs (Fig. 2(c)).

The average $\mathrm{O}: \mathrm{C}$ in the main chamber for the SOA in Experiment AP1 remained practically constant at 0.42 during this experiment. The average $0: C$ of the SOA exiting the TD can be seen in Fig. 3(a). The O:C remained around 0.42 until the temperature reached $125^{\circ} \mathrm{C}$ at which $85 \%$ of the SOA mass had evaporated and the O:C decreased to 0.40. At higher temperatures, the average O:C continued to decrease, reaching 0.33 at $150^{\circ} \mathrm{C}$. At this temperature $5 \%$ of the SOA
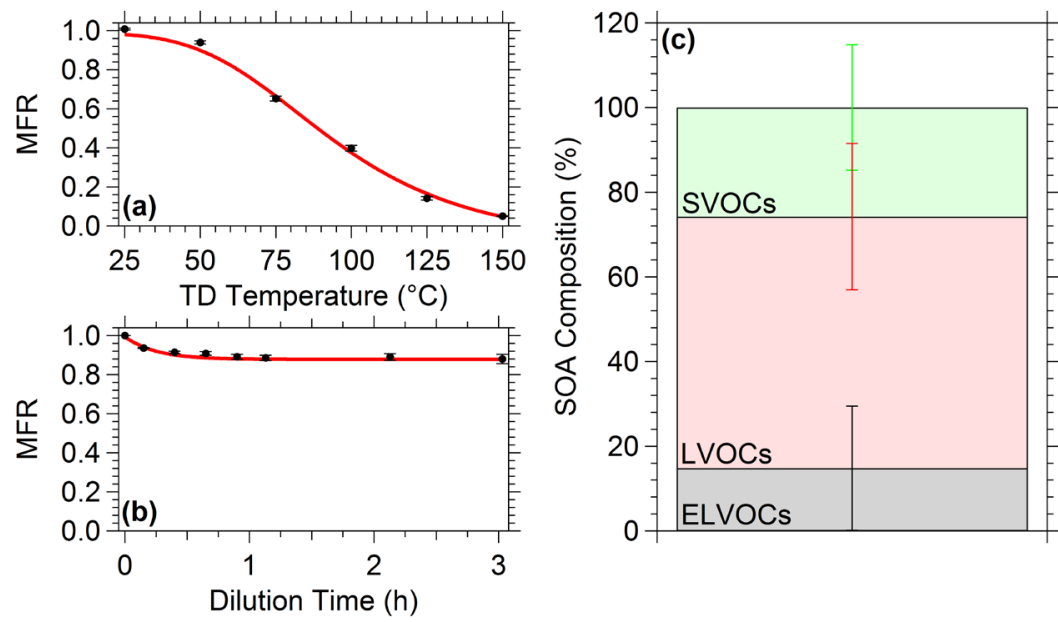

Fig. 2. The (a) thermogram and (b) areogram for Experiment AP1 with fits from the model (red line). The error bars in (a) represent one standard deviation of the mean MFR while the error bars in (b) represent the uncertainty resulting from correcting for particle wall-losses. (c) SOA composition for Experiment AP1 along with their uncertainties ( \pm one standard deviation) from the model. The ELVOCs are shown in grey, LVOCs in red, SVOCs in green, and IVOCs in blue. The uncertainties for the ELVOCS, LVOCS, SVOCS, and IVOCS are shown in black, red, green, and blue respectively. 

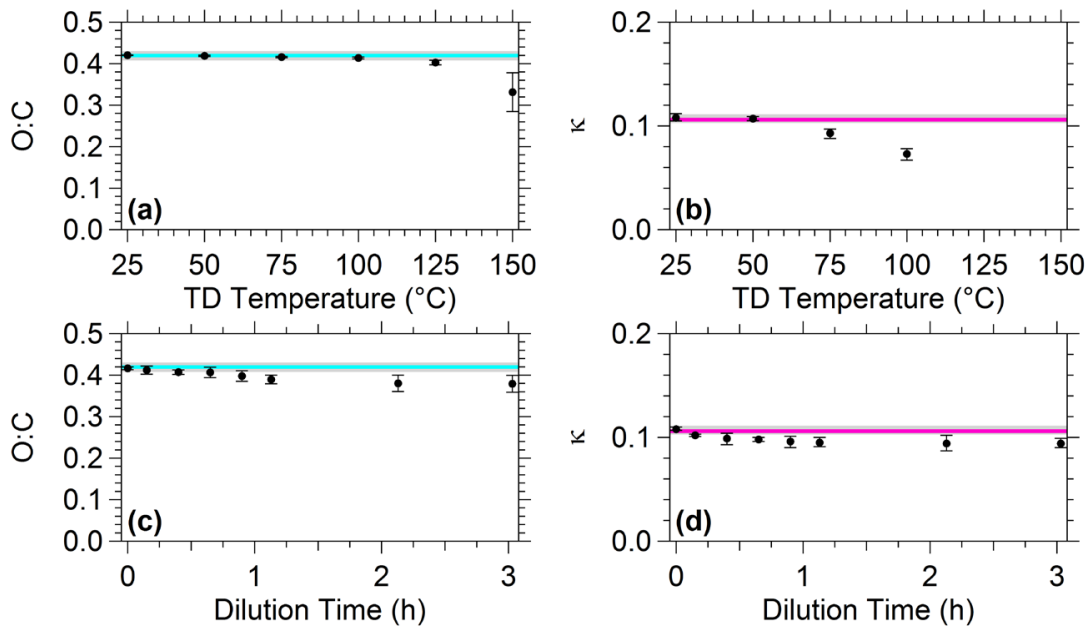

Fig. 3. The (a) O:C and (b) $\kappa$ as a function of TD temperature for Experiment AP1. The (c) O:C and (d) $\kappa$ as a function of dilution time. The error bars represent one standard deviation of the mean O:C or $\kappa$. Also shown are the average 0:C (blue line) and $\kappa$ (magenta line) along with \pm one standard deviation (grey area) of the mean measured in the main chamber during Experiment AP1.

remained, suggesting that the least volatile fraction of the SOA in this experiment had, on average, an $\mathrm{O}: \mathrm{C}$ of 0.33 .

The average $\kappa$ of the SOA in this experiment remained constant at 0.11 in the main chamber. The average $\kappa$ of the SOA exiting the TD was also 0.11 until the temperature reached $75^{\circ} \mathrm{C}$ (Fig. 3(b)). At this temperature, 35\% of the SOA had evaporated and the average $\kappa$ decreased to 0.09. At higher temperatures, as more of the SOA evaporated, the $\kappa$ continued to decrease, reaching a value of 0.07 at $100^{\circ} \mathrm{C}$. This $\kappa$ corresponds to the least volatile $40 \%$ of the SOA. The $15 \%$ of the SOA remaining after evaporation at $125^{\circ} \mathrm{C}$ did not activate at a supersaturation of $0.35 \%$, indicating that the least volatile SOA components had low hygroscopicity.

The average $\mathrm{O}: \mathrm{C}$ and $\kappa$ measured in the dilution chamber as a function of time for Experiment AP1 can also be seen in Fig. 3. The initial O:C and $\kappa$ in the dilution chamber were the same as the average values in the main chamber. However, both the average O:C and $\kappa$ decreased slightly for the first hour and then remained relatively constant for the remainder of the experiment.

The remainder of the $\alpha$-pinene experiments' results can be seen in the supplemental information (Figs. S3-S8). Experiments AP3 and AP4 were conducted at higher SOA concentrations and, as a result, the SVOCs present in the particulate-phase increased to around $50 \%$ of the SOA in these experiments. In general, the SOA had average O:C values around 0.4 and average $\kappa$ values around 0.1 , both consistent with previous observations of $\alpha$-pinene ozonolysis SOA (Engelhart et al., 2008; Huffman et al., 2009; Massoli et al., 2010; Cain and Pandis, 2017). The O:C and $\kappa$ behavior in the TD and dilution chamber for the remaining experiments were similar to the results of Experiment AP1 discussed in the previous paragraphs.

The result of applying the modified Cain and Pandis (2017) method to all of the $\alpha$-pinene experiments can be seen in Fig. 4. The $\alpha$-pinene ozonolysis SOA generated in this study contained SVOCs with an average $0: C$ of $0.46 \pm 0.03$ and $\kappa$ of $0.13 \pm 0.02$, LVOCs with an average $0: C$ of 0.43 \pm 0.02 and $\kappa$ of $0.09 \pm 0.02$, and ELVOCs with an average $0: C$ of $0.28 \pm 0.08$ and $\kappa$ of $0.06 \pm 0.02$. Both the O:C and $\kappa$ values of the LVOCs were statistically lower than those of the SVOCs (alpha $=.05$ ). Furthermore, both the O:C and $\kappa$ values of the ELVOCs were statistically lower than those of the LVOCs (alpha $=.05$ ), indicating that the decrease of O:C and $\kappa$ as volatility decreased was significant.

The $\mathrm{O}: \mathrm{C}$ and $\kappa$ distributions determined in this study are bulk averages for a given volatility class, but each volatility class is comprised of many compounds that vary in O:C and $\kappa$. The $0: C$ distribution in Fig. 4 is consistent with recent results from a study that used a chemical ionization mass spectrometer equipped with a filter inlet for gases and aerosols to characterize the composition of the particulate-phase from the ozonolysis of $\alpha$-pinene at $25^{\circ} \mathrm{C}$ and observed that the O:C of the compounds identified decreased with volatility (Ye et al., 2019). 

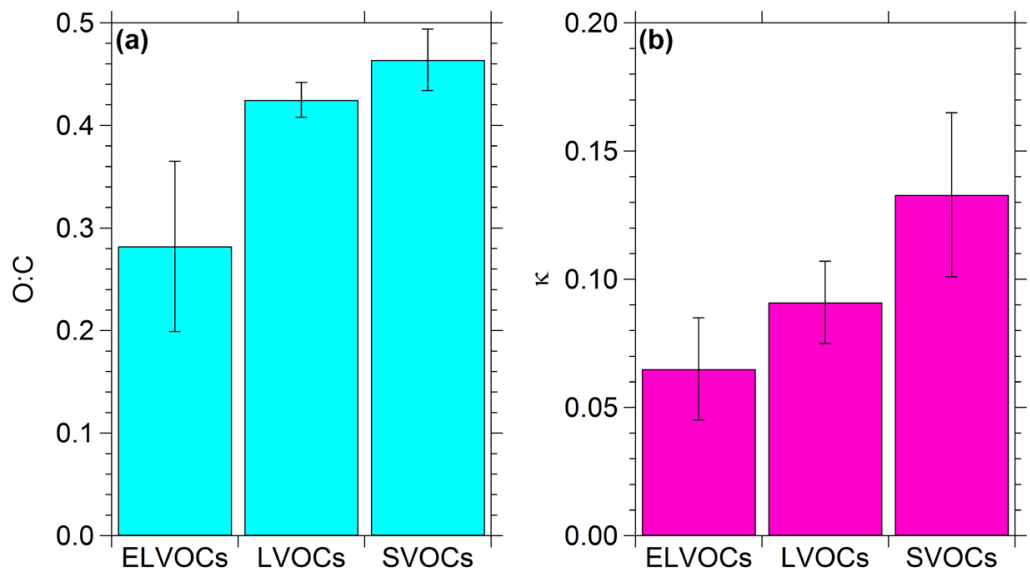

Fig. 4. The (a) O:C and (b) $\kappa$ distributions as a function of volatility for the $\alpha$-pinene ozonolysis SOA examined in this study. The error bars were calculated from the standard deviation that results from determining $\mathrm{O}: \mathrm{C}$ and $\kappa$ distributions for each experiment and represent variability between experiments.

These distributions explain the O:C and $\kappa$ behavior in the TD and dilution chamber. By $75^{\circ} \mathrm{C}$ in the TD, nearly all of the SVOCs had evaporated and the SOA was comprised of mostly LVOCs and ELVOCs (Fig. S2), which had lower $\kappa$ values than the SVOCs. As a result, the average $\kappa$ measured through the TD decreased at this temperature. However, the average $\mathrm{O}: \mathrm{C}$ through the $\mathrm{TD}$ at $75^{\circ} \mathrm{C}$ did not decrease significantly from the average $\mathrm{O}: \mathrm{C}$ in the main chamber because the average O:C of the LVOCs was not that much lower than that of the SVOCs. Once the LVOCs started evaporating at higher temperatures, the average O:C through the TD decreased. Similarly, according to the model, a small fraction of the SVOCs evaporated in the dilution chamber, which caused the $\mathrm{O}: \mathrm{C}$ and $\kappa$ in the dilution chamber to decrease slightly before stabilizing when the evaporation slowed.

\subsection{Limonene Ozonolysis SOA}

The thermogram and areogram, along with fits from the model, for Experiment LM1 are shown in Fig. 5. In this experiment, $8 \%$ of the SOA remained after passing through the TD at $150^{\circ} \mathrm{C}$ and $20 \%$ of the SOA evaporated after being diluted by a factor of 25 . The model reproduced the measured thermogram with deviations of only a few percent and estimated that the SOA was comprised of $9 \%$ ELVOCs, $49 \%$ LVOCs, and $42 \%$ SVOCs.

The O:C of the SOA in the main chamber during Experiment LM1 remained stable at 0.46 . The $\mathrm{O}: \mathrm{C}$ of the SOA exiting the TD increased slightly at 50 and $75^{\circ} \mathrm{C}$ to 0.47 (Fig. $6(\mathrm{a})$ ), indicating that the compounds that evaporated may have slightly lower $\mathrm{O}: \mathrm{C}$ values than the remaining SOA. The $\mathrm{O}: \mathrm{C}$ of the SOA decreased to 0.46 at $100^{\circ} \mathrm{C}$ and, as the temperature increased further, the average O:C of the SOA continued to decrease, reaching 0.39 at $150^{\circ} \mathrm{C}$, indicating that the least volatile components had the lowest oxygen content.

The average $\kappa$ for the SOA in the main chamber for this experiment was 0.10 . The $\kappa$ through the TD in this experiment remained around 0.10 until the temperature reached $75^{\circ} \mathrm{C}$ and then started decreasing, reaching 0.08 at $100^{\circ} \mathrm{C}$ when approximately $50 \%$ of the SOA had evaporated (Fig. $6(\mathrm{~b})$ ). The remaining particles were still $\mathrm{CCN}$ active at $125^{\circ} \mathrm{C}$, but their $\kappa$ decreased even more to 0.04 . After passing through the TD at $150^{\circ} \mathrm{C}$, the remaining $8 \%$ of the SOA did not activate in the CCNC at a SS of $0.32 \%$, indicating that the least volatile compounds in this experiment had low hygroscopicity.

The response of the $\mathrm{O}: \mathrm{C}$ and $\kappa$ to isothermal dilution for the SOA in Experiment LM 1 can also be seen in Fig. 6 . The O:C decreased slowly from the average value in the main chamber throughout the experiment, ending at 0.41 after $5 \mathrm{~h}$ of dilution. The $\kappa$ did not change significantly from the average value in the main chamber. The small difference in the behavior of the O:C compared to that in the dilution chamber is noteworthy. The O:C of the SOA coming out of the TD at low temperatures remained constant or increased slightly, but the O:C in the dilution chamber 

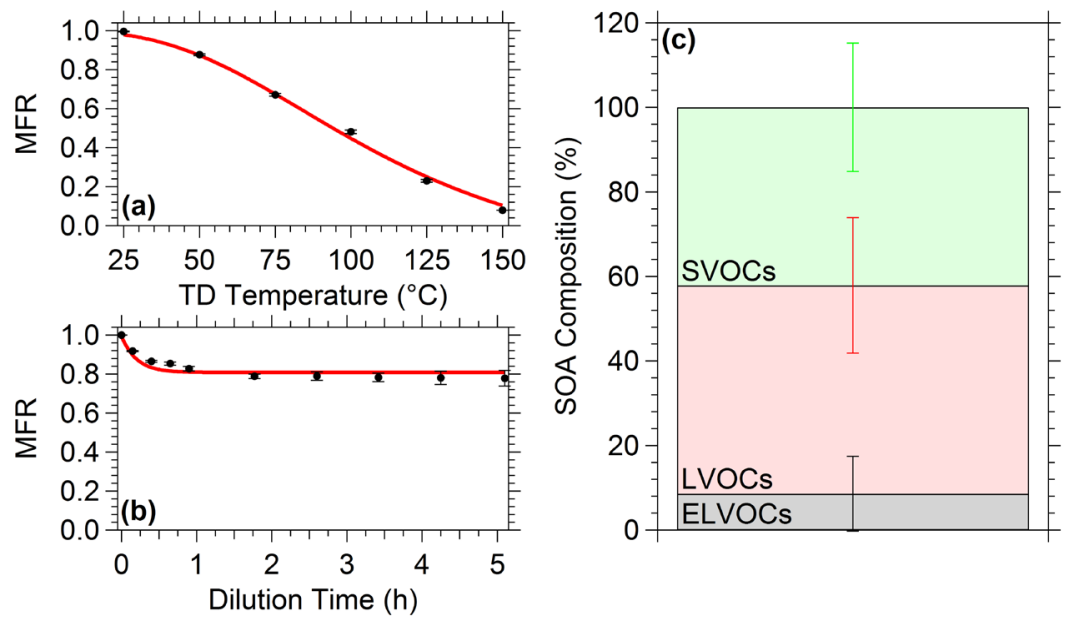

Fig. 5. Same description as Fig. 2, except for Experiment LM1.
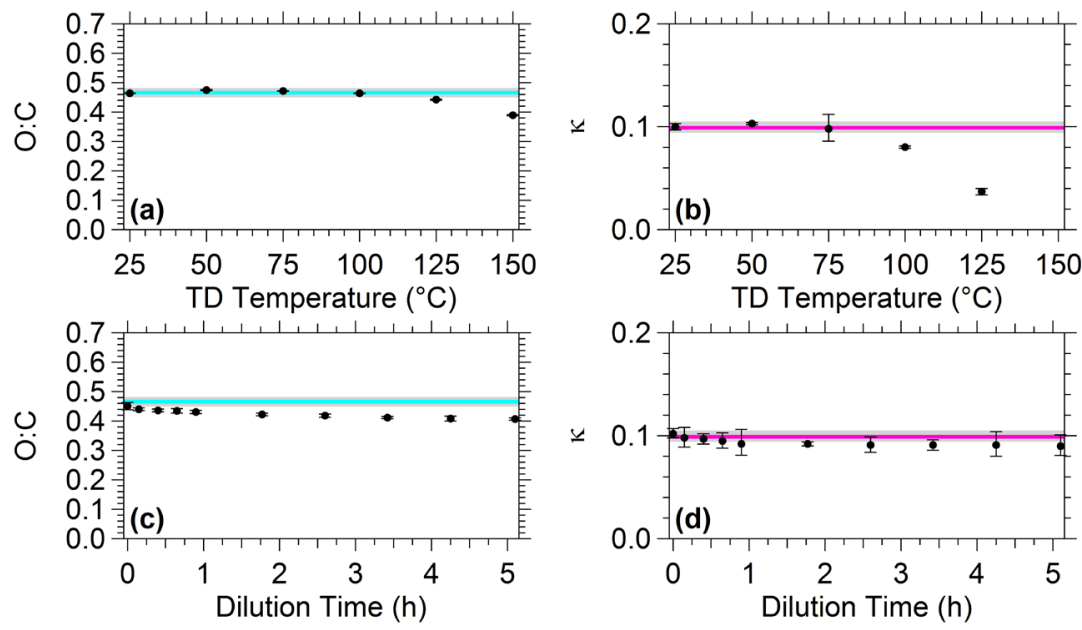

Fig. 6. Same description as Fig. 3, except for Experiment LM1.

decreased slightly. There are a number of potential explanations for this small discrepancy. The evaporation in the TD depends not only on the vapor pressure of the various SOA components at room temperature, but also on their enthalpy of vaporization. The evaporation in the dilution chamber is independent of the enthalpy of vaporization, so it is possible that there were differences in the compounds that evaporated in the two systems for the same amount of evaporated mass. This could also be due to experimental artifacts, including preferential losses of more oxidized semi-volatile SOA components in our transfer system to the dilution chamber or reactions in the TD. Even if this discrepancy is relatively small, it probably requires additional investigation with measurements of the molecular composition of both the particulate and vapor-phases in future work.

The results from Experiments LM2 and LM3 can be seen in the supplemental information (Figs. S10-S13). The SOA from these experiments had similar composition to the SOA in Experiment LM 1 and average O:C and $\kappa$ values around 0.47 and 0.1 respectively. The behavior of the O:C and $\kappa$ in the TD and dilution chamber for these experiments were similar to the results from Experiment LM1.

The average $\mathrm{O}: \mathrm{C}$ and $\kappa$ distributions for the limonene ozonolysis SOA based on all experiments can be seen in Fig. 7. The limonene ozonolysis SOA generated in this study had SVOCs with an average $0: C$ of $0.46 \pm 0.11$ and $\kappa$ of $0.11 \pm 0.02$, LVOCs with an average $0: C$ of $0.57 \pm 0.08$ and $\kappa$ of $0.12 \pm 0.02$, and ELVOCs with an average $0: C$ of $0.30 \pm 0.09$ and $\kappa$ of $0.02 \pm 0.02$. The $0: C$ and $\kappa$ values of the LVOCs were not statistically different from those of the SVOCs (alpha $=.05$ ), but 

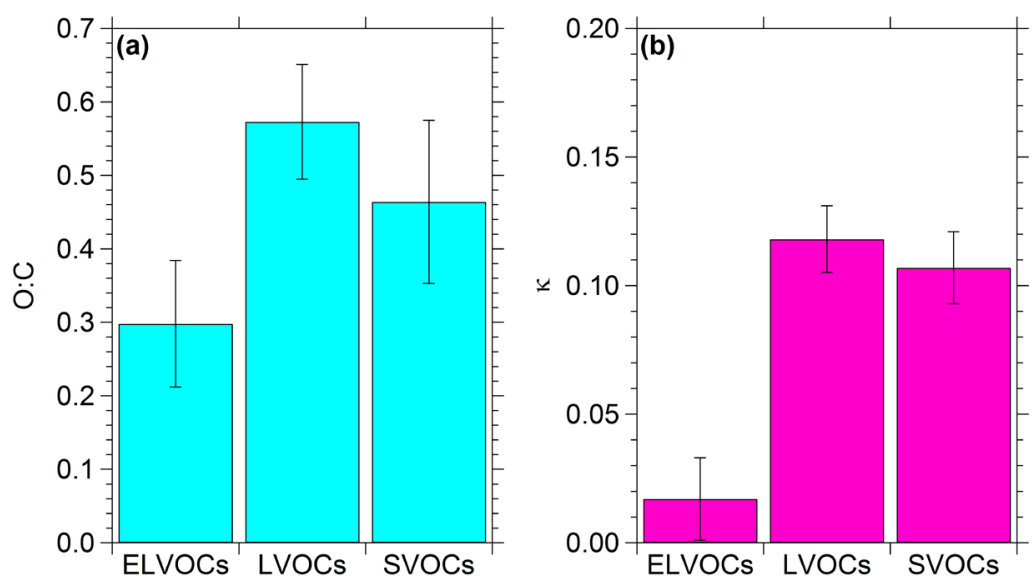

Fig. 7. Same description as Fig. 4, except for limonene ozonolysis SOA.

the O:C and $\kappa$ values of the ELVOCs were statistically smaller than the values of both the SVOCs and LVOCs (alpha $=0.05$ ).

\subsection{Cyclohexene Ozonolysis SOA}

The thermogram and areogram with fits from the model for Experiment $\mathrm{CH} 1$ can be seen in Fig. 8. The SOA in this experiment evaporated more at the same TD temperature than the SOA produced during the ozonolysis of the two monoterpenes. At $25^{\circ} \mathrm{C}$, there was non-negligible evaporation as the MFR decreased to 0.93 , which Cain et al. (2020) attributed to the activated carbon in the cooling section stripping the most volatile components from the particles. Furthermore, despite only being diluted by a factor of $9,25 \%$ of the SOA evaporated in the dilution chamber, indicating that this SOA included a significant fraction of relatively volatile components. The model estimated that the SOA in this experiment was more volatile than the monoterpene ozonolysis SOA with $11 \%$ IVOCs, $46 \%$ SVOCs, and $43 \%$ LVOCs. The IVOCs were responsible for, according to the model, the evaporation at room temperature in the TD and also for approximately half of the evaporation in the dilution chamber in all experiments.

The average $\mathrm{O}: \mathrm{C}$ of the SOA in the main chamber for Experiment $\mathrm{CH} 1$ was constant around 0.55 . The evaporation of the most volatile $7 \%$ of the SOA mass at $25^{\circ} \mathrm{C}$ led to an increase of the average O:C through the TD to 0.56 (Fig. 9(a)). This small amount of evaporated mass was almost exclusively IVOCs. The detectable increase in the O:C suggests that these IVOCs had lower O:C values than the less volatile SOA. The O:C remained at this slightly elevated value until the temperature reached $75^{\circ} \mathrm{C}$, where $50 \%$ of the SOA mass had evaporated, and then it began to decrease, ending at 0.45 at $150^{\circ} \mathrm{C}$.

Calculating the $\kappa$ for this experiment using the surface tension of water resulted in an apparent $\kappa$ of 0.85 . Therefore, knowing that some of the oxidation products of cycloalkene ozonolysis SOA are small and amphiphilic (Asa-Awuku et al., 2010), we attempted to measure the surface tension of our SOA droplets by collecting the SOA on a quartz filter and extracting the water soluble organic carbon according to the method outlined in Liangou et al. (2020) for analysis with a novel microtensiometer (Alvarez et al., 2010; Reichert et al., 2015). However, none of the samples demonstrated significant surface tension depression, indicating that if there are surface active compounds, they were not concentrated enough in the extracted samples. Asa-Awuku et al. (2010) were also unable to observe surface tension depression for cycloheptene ozonolysis SOA, but inferred that cycloheptene ozonolysis SOA with $33 \%$ ammonium sulfate had a surface tension of $0.06 \mathrm{~J} \mathrm{~m}^{-2}$. Given that only one methylene group separates cycloheptene from cyclohexene and that adding ammonium sulfate drives the surface tension of the droplets towards that of water (Asa-Awuku et al., 2010), we assumed a surface tension of $0.05 \mathrm{~J} \mathrm{~m}^{-2}$ for all of the cyclohexene ozonolysis SOA in this study. Using this surface tension resulted in an average $\kappa$ of 0.28 for Experiment $\mathrm{CH} 1$, which is similar to the $\kappa$ of 0.25 observed in Asa-Awuku et al. (2010) for cycloheptene ozonolysis SOA. It is also possible that some of the volatile products from this reaction may be partially dissolving in the droplets formed in the CCNC thus enhancing the CCN 

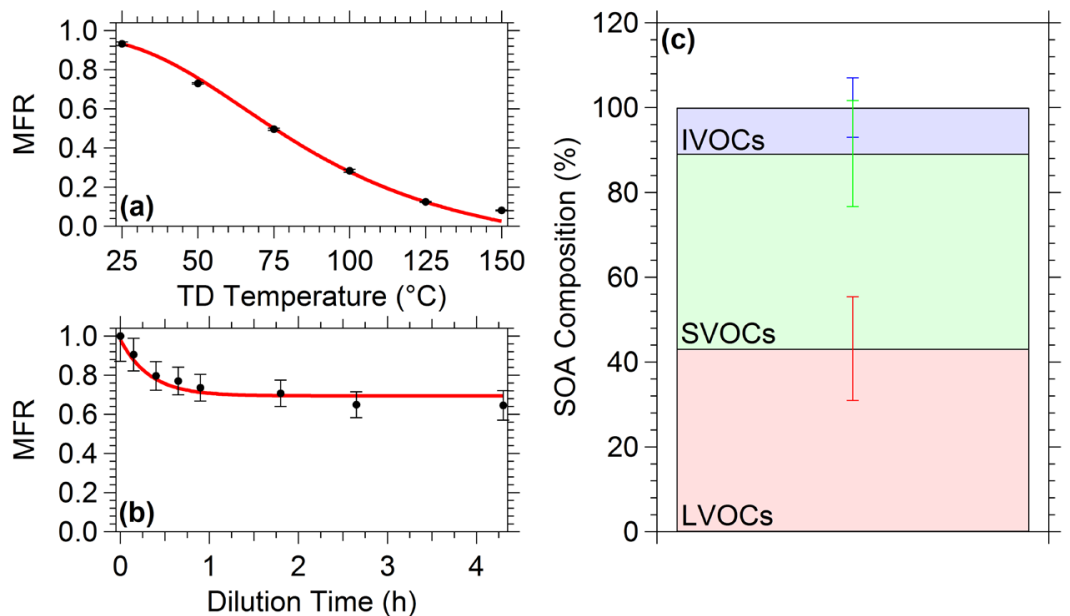

Fig. 8. Same description as Fig. 2, except for Experiment $\mathrm{CH} 1$.
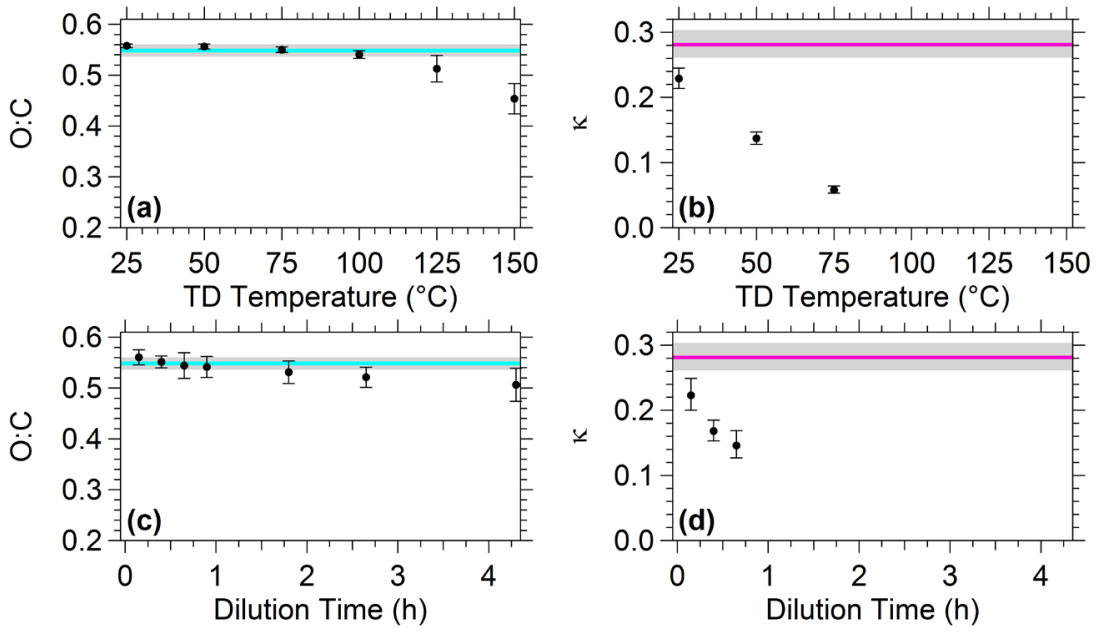

Fig. 9. Same description as Fig. 3, except for Experiment $\mathrm{CH}$.

activity (Kroll et al., 2005; Donaldson and Vaida, 2006; Ervens and Volkamer, 2010; Sareen et al., 2013). If these volatile compounds are indeed contributing to the observed CCN activity, then our estimate of a $\kappa$ with a surface tension of $0.05 \mathrm{~J} \mathrm{~m}^{-2}$ may be too high and provides more of an upper bound on the SOA hygroscopicity.

The evaporation of the IVOCs caused by the activated carbon at $25^{\circ} \mathrm{C}$ led to a significant decrease in hygroscopicity with the $\kappa$ dropping to 0.23 (Fig. 9(b)). The $\kappa$ continued to decrease rapidly as temperature increased and the SOA did not activate at temperatures above $75^{\circ} \mathrm{C}$. It is also possible that, since the activated carbon removes all vapor-phase compounds, if there was any vapor-phase dissolution, the enhanced CCN activity was removed. In any case, these results strongly suggest that the relatively more volatile products (IVOCs and maybe some VOCs) of the cyclohexene ozonolysis reaction are responsible for a significant fraction of the observed high CCN activity.

The average $\mathrm{O}: \mathrm{C}$ and $\kappa$ measured in the dilution chamber as a function of time for Experiment $\mathrm{CH} 1$ can also be seen in Fig. 9. The initial O:C and $\kappa$ in the dilution chamber could not be measured due to the evaporation occurring before the instruments could obtain the first sample. The comparison of the first measured O:C values in the dilution chamber (after the chamber equilibrated) with those in the main chamber suggest an increase of the $0: C$ during this initial evaporation. This behavior is consistent with that observed in the TD. The $\kappa$ decreased rapidly after dilution from the average value in the main chamber until the CCN concentration was too low to average. Given that the sample did not pass through activated carbon for these CCN 
measurements this behavior indicates that the IVOCs in the SOA were probably responsible for the high CCN activity.

The results from the four other cyclohexene ozonolysis SOA experiments can be found in the supplemental information (Figs. S15-S22). The SOA in these experiments had an average O:C of 0.55 and $\kappa$ values around and 0.3 . The SOA in all of these experiments had similar behavior in the TD and dilution chamber to Experiment $\mathrm{CH} 1$.

In order to estimate the $\mathrm{O}: \mathrm{C}$ and $\kappa$ distributions, we used the average values from the main chamber for the $\mathrm{O}: \mathrm{C}$ and $\kappa$ at the TD temperature of $25^{\circ} \mathrm{C}$ and $t=0 \mathrm{~h}$ in the dilution chamber. The resulting $\mathrm{O}: \mathrm{C}$ and $\kappa$ distributions as a function of volatility for all experiments can be seen in Fig. 10 . These results indicated that the cyclohexene ozonolysis SOA formed in this study was comprised of IVOCs with an average O:C of $0.33 \pm 0.03$ and $\kappa$ of $0.80 \pm 0.10$, SVOCs with an average O:C of $0.57 \pm 0.03$ and $\kappa$ of $0.36 \pm 0.10$, and LVOCs with an average $0: C$ of $0.54 \pm 0.02$ and $\kappa$ of $0.05 \pm$ 0.01 . The changes of the $\mathrm{O}: \mathrm{C}$ and $\kappa$ values as volatility decreased were statistically significant (alpha $=.05)$. The absolute values in the $\kappa$ distribution are quite uncertain because we had to assume a surface tension, but the trend of decreasing hygroscopicity with volatility is quite robust.

The distributions in Fig. 10 quantitatively describe the $0: C$ and $\kappa$ behavior in the TD and dilution chamber. The small increase in O:C and significant decrease in $\kappa$ of the SOA through the TD at $25^{\circ} \mathrm{C}$ can be attributed to the activated carbon stripping the IVOCs. Thus, increasing the average $\mathrm{O}: \mathrm{C}$ and decreasing the average $\kappa$ of the resulting SOA. The mass transfer model estimated that nearly all of SVOCs in Experiment $\mathrm{CH} 1$ evaporated at $100^{\circ} \mathrm{C}$ (Fig. S14), which caused the decrease in the average $\mathrm{O}: \mathrm{C}$ of the SOA exiting the TD. Similarly, the $\mathrm{O}: \mathrm{C}$ in the dilution chamber increased from the rapid evaporation of the IVOCs and then decreased slowly as the SVOCs with the highest $\mathrm{O}: \mathrm{C}$ values evaporated.

\subsection{D-VBS Synthesis}

The distributions determined in this study can be implemented directly in the 2D-VBS framework (Fig. 11). The $x$-axis in this figure is the logarithm of the effective saturation concentration, $C^{*}$, and the $y$-axis is the O:C (Donahue et al., 2011). The 2D-VBS allows for a direct comparison with the $\kappa$ predictions from Nakao (2017).

The model predictions from Nakao (2017) are quite consistent with our distributions for the $\alpha$ pinene and limonene SOA components. The SVOCS and LVOCS are quite consistent with the $\kappa=$ 0.1 isoline and the corresponding predictions in this area of the 2D-VBS. For example, the LVOCs in the limonene ozonolysis SOA had a higher average O:C than the SVOCs, so conventional thinking would indicate that the LVOCs should be more hygroscopic (Jimenez et al., 2009). However, both our measurements and the $\kappa=0.1$ isoline suggest that these compounds have similar hygroscopicity. This demonstrates that, at least in this system, the O:C can increase for less volatile components while the hygroscopicity remains constant. The ELVOCs for both systems are in the lower left corner of the 2D-VBS, agreeing with the predictions from Nakao (2017) that compounds in this area will have relatively low hygroscopicity.
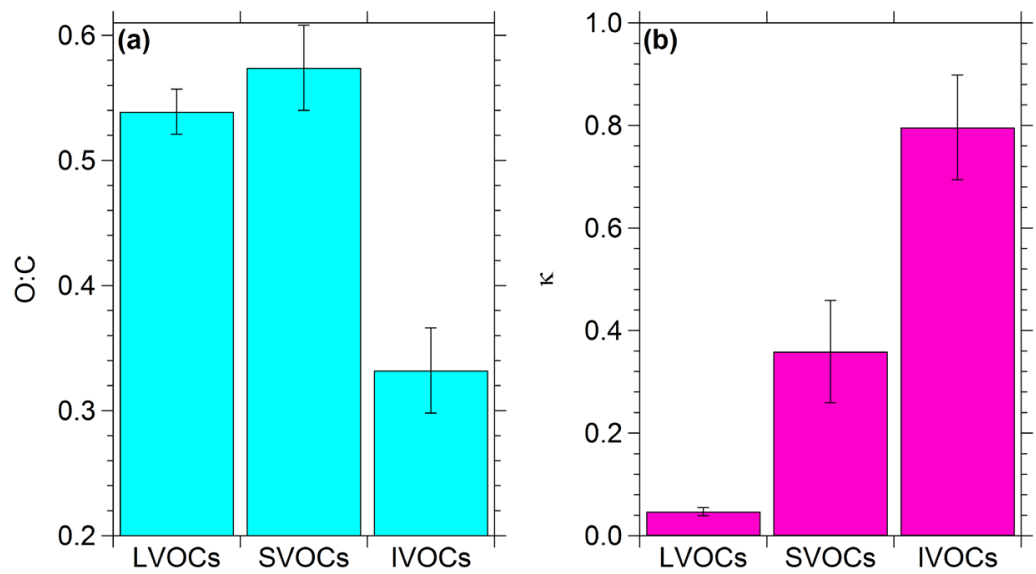

Fig. 10. Same description as Fig. 4, except for cyclohexene ozonolysis SOA. 


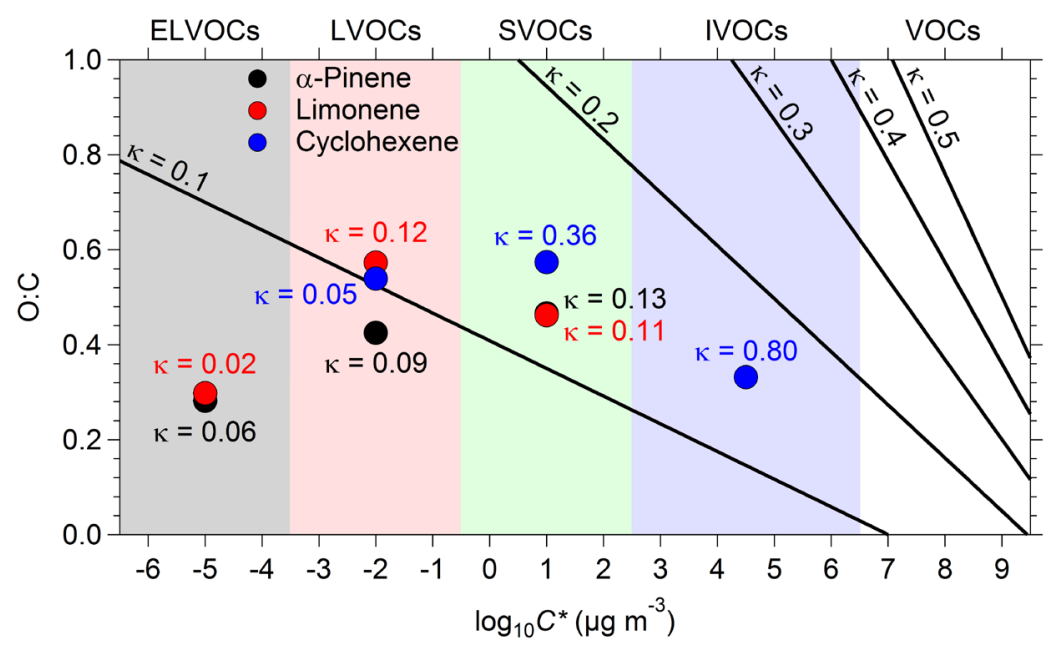

Fig. 11. The $O: C$ and $\kappa$ distributions as a function of volatility for the $\alpha$-pinene (black), limonene (red), and cyclohexene (blue) ozonolysis SOA. The data points represent the average O:C for a volatility class while the average $\kappa$ is indicated in the figure. The distributions are presented in the 2D-VBS framework where the shaded regions indicate the ELVOCs, LVOCs, SVOCs, IVOCs, and VOCs according to their effective saturation concentration. Also shown are the lines of constant $\kappa$ predicted by Nakao (2017).

The hygroscopicity results for the IVOCs and SVOCs for the cyclohexene ozonolysis SOA are not consistent with the predictions from Nakao (2017). The hygroscopicity of the LVOCs, considering the uncertainty in our assumed surface tension, is less inconsistent with the Nakao (2017) model. Our results suggest that improvements may be possible for the model in the areas of higher predicted hygroscopicity. However, these are the most uncertain estimates in our measurements, so the discrepancy may be a lot smaller than what Fig. 11 indicates. Studies in that area of the 2D-VBS would be quite helpful in determining if the behavior of the cyclohexene ozonolysis SOA is an outlier or if it is representative of the ambient SOA components in that region.

\subsection{Benefit of Isothermal Dilution Measurements}

To demonstrate the benefit of adding isothermal dilution measurements to the technique, we repeated the analysis of our results without including the isothermal dilution measurements. The $\mathrm{O}: \mathrm{C}$ and $\kappa$ distributions as a function of volatility with and without isothermal dilution measurements for all three SOA systems can be seen in Figs. S23-S25. The first improvement is that the inclusion of the isothermal dilution measurements constrains the SVOCs and LVOCS better, allowing for the estimation of the properties of the IVOCs or ELVOCs, depending on the system. Our ability to estimate the properties of these compounds in this study was due, to a large extent, to the availability of these additional measurements. The second benefit is the reduction of the uncertainties of the properties of the various volatility classes. The uncertainty in the distributions for the SVOCS and LVOCs was decreased by a factor of two with the addition of the dilution measurements. This comparison indicates that adding isothermal dilution measurements can be beneficial to understanding the relationship between hygroscopicity, oxidation level, and volatility of OA.

\section{CONCLUSIONS}

A technique that quantitatively relates hygroscopicity and oxidation level as a function of volatility was tested with SOA from the ozonolysis of $\alpha$-pinene, limonene, and cyclohexene. The technique builds upon the approach of Cain and Pandis (2017), which separated SOA by volatility with a TD, by adding isothermal dilution measurements and observing the $\mathrm{O}: \mathrm{C}$ and $\kappa$ of the resulting SOA. The technique then determines $\mathrm{O}: \mathrm{C}$ and $\kappa$ distributions as a function of volatility that can be used to describe the SOA. 
The O:C and $\kappa$ distributions determined for the $\alpha$-pinene ozonolysis SOA examined in this study indicated that the average $\mathrm{O}: \mathrm{C}$ and $\kappa$ decreased as volatility decreased. The average O:C and $\kappa$ of the SVOCS and LVOCS of SOA from the ozonolysis of limonene were similar, but the ELVOCs had lower oxygen content and hygroscopicity.

The SVOCs and ELVOCs formed during the limonene ozonolysis had nearly identical O:C and $\kappa$ values as the SVOCs and ELVOCs of the $\alpha$-pinene ozonolysis SOA respectively. However, the LVOCs of the limonene ozonolysis SOA had higher average O:C and $\kappa$ values than the average values of the LVOCs from the $\alpha$-pinene ozonolysis SOA. The increased O:C of the LVOCs could be a result of the second double bond in limonene and increased reactivity towards ozone. Both SOA systems had ELVOCs with the lowest O:C and $\kappa$ values. The O:C distribution of the $\alpha$-pinene Ozonolysis SOA is consistent with recent results studying the composition of $\alpha$-pinene ozonolysis SOA, which indicated that O:C decreased with volatility (Ye et al., 2019). The decrease in hygroscopicity with the ELVOCs could be explained by low solubility of the higher molecular weight products and is further supported by their lower $\mathrm{O}: \mathrm{C}$ values. It is important to note that our measurements indicate bulk averages. Our results do not rule out the existence of highly oxidized ELVOCs, but they simply suggest that they are, on average, less oxidized than the higher volatility components.

The O:C and $\kappa$ distributions of the cyclohexene ozonolysis SOA indicated that the relationship between these three properties can be more complex for some OA systems. The average O:C of this SOA increased as volatility decreased, but its average $\kappa$ decreased as volatility decreased. Even though the absolute values in the $\kappa$ distribution for this SOA are quite uncertain due an assumed surface tension, these results suggest that even relatively volatile SOA components with small mass yields could, under some conditions, impact the CCN budget.

This work differs from Cain and Pandis (2017) due to the addition of the isothermal dilution measurements. The addition of the isothermal dilution measurements allows for the distributions to be extended over a larger range of volatility. Furthermore, the uncertainty of the distributions is reduced when isothermal dilution measurements are included due to the additional information about the more volatile OA components, which provides more information for the optimization process.

Complications that cannot be addressed in this work are the roles of reactions and possible oligomer decomposition at high TD temperatures and in the dilution chamber. Our analysis assumes that these complications are negligible, but without high-resolution molecular composition measurements of both the particulate and vapor-phases, we cannot definitively rule it out. The importance of complete molecular information in evaporation studies cannot be understated. Complicating matters further are the possible changes in surface tension as the SOA evaporates. It is plausible that surface active components could evaporate at a low TD temperature or immediately in the dilution chamber, but our analysis assumes that the surface tension remains constant for all SOA as they evaporate.

More importantly, although not at atmospherically relevant concentrations, these results provide insights into SOA components. For example, most of the CCN activity of $\alpha$-pinene ozonolysis SOA comes from SVOCs and LVOCs. In addition, the 2D-VBS framework can be used to integrate the results. Use of this technique with different OA systems, both laboratory and ambient, can supply parameters that can be incorporated in atmospheric chemical transport models.

\section{ACKNOWLEDGEMENTS}

This publication was developed as part of the Center for Air, Climate, and Energy Solutions (CACES), which was supported under Assistance Agreement No. R835873 awarded by the U.S. Environmental Protection Agency. It has not been formally reviewed by EPA. The views expressed in this document are solely those of authors and do not necessarily reflect those of the Agency. EPA does not endorse any products or commercial services mentioned in this publication. This work was also supported by the National Science Foundation grant 1455244 and the Carnegie Mellon University Steinbrenner Institute Robert W. Dunlap Fellowship. 


\section{SUPPLEMENTARY MATERIAL}

Supplementary data associated with this article can be found in the online version at https://doi.org/10.4209/aaqr.2020.08.0511

\section{REFERENCES}

Alroe, J., Cravigan, L.T., Mallet, M.D., Ristovski, Z.D., Miljevic, B., Osuagwu, C.G., Johnson, G.R. (2018). Determining the link between hygroscopicity and composition for semi-volatile aerosol species. Atmos. Meas. Tech. 11, 4361-4372. https://doi.org/10.5194/amt-11-4361-2018

Alvarez, N.J., Walker, L.M., Anna, S.L. (2010). A microtensiometer to probe the effect of radius of curvature on surfactant transport to a spherical interface. Langmuir 26, 13310-13319. https://doi.org/10.1021/la101870m

Asa-Awuku, A., Nenes, A., Gao, S., Flagan, R.C., Seinfeld, J.H. (2010). Water-soluble SOA from alkene ozonolysis: Composition and droplet activation kinetics inferences from analysis of CCN activity. Atmos. Chem. Phys. 10, 1585-1597. https://doi.org/10.5194/acp-10-1585-2010

Bahreini, R., Keywood, M.D., Ng, N.L., Varutbangkul, V., Gao, S., Flagan, R.C., Seinfeld, J.H., Worsnop, D.R., Jimenez, J.L. (2005). Measurements of secondary organic aerosol from oxidation of cycloalkenes, terpenes, and m-xylene using an aerodyne aerosol mass spectrometer. Environ. Sci. Technol. 39: 5674-5688. https://doi.org/10.1021/es048061a

Cain, K.P., Pandis, S.N. (2017). A technique for the measurement of organic aerosol hygroscopicity, oxidation level, and volatility distributions. Atmos. Meas. Tech. 10, 4865-4876. https://doi.org/10.5194/amt-10-4865-2017

Cain, K.P., Karnezi, E., Pandis, S.N. (2020). Challenges in determining atmospheric organic aerosol volatility distributions using thermal evaporation techniques. Aerosol Sci. Technol. 54, 941957. https://doi.org/10.1080/02786826.2020.1748172

Canagaratna, M.R., Jimenez, J.L., Kroll, J.H., Chen, Q., Kessler, S.H., Massoli, P., Hildebrandt Ruiz, L., Forner, E., Williams, L.R., Wilson, K.R., Surratt, J.D., Donahue, N.M., Jayne, J.T., Worsnop, D.R. (2015). Elemental ratio measurements of organic compounds using aerosol mass spectrometry: Characterization, improved calibration, and implications. Atmos. Chem. Phys. 15, 253-272. https://doi.org/10.5194/acp-15-253-2015

Cerully, K.M., Bougiatioti, A., Hite Jr., J.R., Guo, H., Xu, L., Ng, N.L., Weber, R., Nenes, A. (2015) On the link between hygroscopicity, volatility, and oxidation state of ambient and watersoluble aerosols in the southeastern United States. Atmos. Chem. Phys. 15, 8679-8694. https://doi.org/10.5194/acp-15-8679-2015

Chen, X., Hopke, P.K. (2010). A chamber study of secondary organic aerosol formation by limonene ozonolysis. Indoor Air 20, 320-328. https://doi.org/10.1111/j.1600-0668.2010.00656.x

Ditto, J.C., Barnes, E.B., Khare, P., Takeuchi, M., Joo, T., Bui, A.A.T., Lee-Taylor, J., Eris, G., Chen, Y., Aumont, B., Jimenez, J.L., Ng, N.L., Griffin, R.J., Gentner, D.R. (2018). An omnipresent diversity and variability in the chemical composition of atmospheric functionalized organic aerosol. Comm. Chem. 1, 75. https://doi.org/10.1038/s42004-018-0074-3

Donahue, N.M., Chuang, W., Epstein, S.A., Kroll, J.H., Worsnop, D.R., Robinson, A.L., Adams, P.J., Pandis, S.N. (2013). Why do organic aerosols exist? Understanding aerosol lifetimes using the twodimensional volatility basis set. Environ. Chem. 10, 151-157. https://doi.org/10.1071/EN13022

Donahue, N.M., Robinson, A.L., Stanier, C.O., Pandis, S.N. (2006). Coupled partitioning, dilution, and chemical aging of semivolatile organics. Environ. Sci. Technol. 40, 2635-2643. https://doi.org/10.1021/es052297c

Donahue, N.M., Epstein, S.A., Pandis, S.N., Robinson, A.L. (2011). A two-dimensional volatility basis set, 1. Organic-aerosol mixing thermodynamics. Atmos. Chem. Phys. 11, 3303-3318. https://doi.org/10.5194/acp-11-3303-2011

Donaldson, D.J., Vaida, V. (2006). The influence of organic films at the air-aqueous boundary on atmospheric processes. Chem. Rev. 106, 1445-1461. https://doi.org/10.1021/cr040367c

Ervens, B., Volkamer, R. (2010). Glyoxal processing by aerosol multiphase chemistry: Towards a kinetic modeling framework of secondary organic aerosol formation in aqueous particles. Atmos. Chem. Phys. 10, 8219-8244. https://doi.org/10.5194/acp-10-8219-2010 
Frosch, M., Bilde, M., DeCarlo, P. F., Jurányi, Z., Tritscher, T., Dommen, J., Donahue, N.M., Gysel, M., Weingartner, E., Baltensperger, U. (2011). Relating cloud condensation nuclei activity and oxidation level of $\alpha$-pinene secondary organic aerosols. J. Geophys. Res. 116, D22212. https://doi.org/10.1029/2011JD016401

Gao, S., Keywood, M., Ng, N.L., Surratt, J., Varutbangkul, V., Bahreini, R., Flagan, R.C., Seinfeld, J. H. (2004). Low-molecular-weight and oligomeric components in secondary organic aerosol from the ozonolysis of cycloalkenes and $\alpha$-pinene. J. Phys. Chem. 108, 10147-10164. https://doi.org/10.1021/jp047466e

Hallquist, M., Wenger, J.C., Baltensperger, U., Rudich, Y., Simpson, D., Claeys, M., Dommen, J., Donahue, N.M., George, C., Goldstein, A.H., Hamilton, J.F., Herrmann, H., Hoffmann, T., linuma, Y., Jang, M., Jenkin, M.E., Jimenez, J.L., Kiendler-Scharr, A., Maenhaut, W., McFiggans, G., ... Wildt, J. (2009). The formation, properties and impact of secondary organic aerosol: Current and emerging issues. Atmos. Chem. Phys. 9, 5155-5236. https://doi.org/10.5194/acp9-5155-2009

Hansel, A., Scholz, W., Mentler, B., Fischer, L., Berndt, T. (2018). Detection of $\mathrm{RO}_{2}$ radicals and other products from cyclohexene ozonolysis with $\mathrm{NH}_{4}{ }^{+}$and acetate chemical ionization mass spectrometry. Atmos. Environ. 186, 248-255. https://doi.org/10.1016/j.atmosenv.2018.04.023

Heald, C.L., Kroll, J.H., Jimenez, J.L., Docherty, K.S., Decarlo, P.F., Aiken, A.C., Chen, Q., Martin, S.T., Farmer, D.K., Artaxo, P. (2010). A simplified description of the evolution of organic aerosol composition in the atmosphere. Geophys. Res. Lett. 37, L08803. https://doi.org/10.1029/2010 GL042737

Heaton, K.J., Dreyfus, M.A., Wang, S., Johnston, M.V. (2007). Oligomers in the early stage of biogenic secondary organic aerosol formation and growth. Environ. Sci. Technol. 41, 61296136. https://doi.org/10.1021/es070314n

Hildebrandt Ruiz, L., Paciga, A.L., Cerully, K.M., Nenes, A., Donahue, N.M., Pandis, S.N. (2015). Formation and aging of secondary organic aerosol from toluene: Changes in chemical composition, volatility, and hygroscopicity. Atmos. Chem. Phys. 15, 8301-8313. https://doi.org/10.5194/acp-15-8301-2015

Hong, J., Häkkinen, S.A.K., Paramonov, M., Äijälä, M., Hakala, J., Nieminen, T., Mikkilä, J., Prisle, N.L., Kulmala, M., Riipinen, I., Bilde, M., Kerminen, V.M., Petäjä, T. (2014). Hygroscopicity, CCN and volatility properties of submicron atmospheric aerosol in a boreal forest environment during the summer of 2010. Atmos. Chem. Phys. 14, 4733-4748. https://doi.org/10.5194/acp14-4733-2014

Huff Hartz, K.E., Rosenørn, T., Ferchak, S.R., Raymond, T.M., Bilde, M., Donahue, N.M., Pandis, S.N. (2005). Cloud condensation nuclei activation of monoterpene and sesquiterpene secondary organic aerosol. J. Geophys. Res. 110, D14208. https://doi.org/10.1029/2004JD005754

Huffman, J.A., Docherty, K.S., Mohr, C., Cubison, M.J., Ulbrich, I.M., Ziemann, P.J., Onasch, T.J., Jimenez, J.L. (2009). Chemically-resolved volatility measurements of organic aerosol from different sources. Environ. Sci. Technol. 43, 5351-5357. https://doi.org/10.1021/es803539d

Hyttinen, N., Rissanen, M.P., Kurtén, T. (2017). Computational comparison of acetate and nitrate chemical ionization of highly oxidized cyclohexene ozonolysis intermediates and products J. Phys. Chem. 121, 2172-2179. https://doi.org/10.1021/acs.jpca.6b12654

Jimenez, J.L., Canagaratna, M.R., Donahue, N.M., Prevot, A.S.H., Zhang, Q., Kroll, J.H., DeCarlo, P.F., Allan, J.D., Coe, H., Ng, N.L., Aiken, A.C., Docherty, K.S., Ulbrich, I.M., Grieshop, A.P., Robinson, A.L., Duplissy, J., Smith, J.D., Wilson, K.R., Lanz, V.A., Hueglin, C., ... Worsnop, D.R. (2009). Evolution of organic aerosols in the atmosphere. Science 326, 1525-1529. https://doi.org/10. 1126/science.1180353

Kalberer, M., Yu, J., Cocker, D.R., Flagan, R.C., Seinfeld, J.H. (2000). Aerosol formation in the cyclohexene-ozone system. Environ. Sci. Technol. 34, 4894-4901. https://doi.org/10.1021/es 001180f

Kanakidou, M., Seinfeld, J.H., Pandis, S.N., Barnes, I., Dentener, F.J., Facchini, M.C., Van Dingenen, R., Ervens, B., Nenes, A., Nielsen, C.J., Swietlicki, E., Putaud, J.P., Balkanski, Y., Fuzzi, S., Horth, J., Moortgat, G.K., Winterhalter, R., Myhre, C.E.L., Tsigaridis, K., Vignati, E., ... Wilson, J. (2005). Organic aerosol and global climate modelling: A review. Atmos. Chem. Phys. 5, 1053-1123. https://doi.org/10.5194/acp-5-1053-2005

Karnezi, E., Riipinen, I., Pandis, S.N. (2014). Measuring the atmospheric organic aerosol volatility 
distribution: A theoretical analysis. Atmos. Meas. Tech. 7, 2953-2965. https://doi.org/10.519 4/amt-7-2953-2014

Keywood, M.D., Kroll, J.H., Varutbangkul, V., Bahreini, R., Flagan, R.C., Seinfeld, J.H. (2004a). Secondary organic aerosol formation from cyclohexene ozonolysis: Effect of $\mathrm{OH}$ scavenger and the role of radical chemistry. Environ. Sci. Technol. 38, 3343-3350. https://doi.org/10.1021/es 049725j

Keywood, M.D., Varutbangkul, V., Bahreini, R., Flagan, R.C., Seinfeld, J.H. (2004b). Secondary organic aerosol formation from the ozonolysis of cycloalkenes and related compounds. Environ. Sci. Technol. 38, 4157-4164. https://doi.org/10.1021/es035363o

Kostenidou, E., Karnezi, E., Hite Jr., J.R., Bougiatioti, A., Cerully, K., Xu, L., Ng, N.L., Nenes, A., Pandis, S.N. (2018). Organic aerosol in the summertime southeastern United States: Components and their link to volatility distribution, oxidation state and hygroscopicity. Atmos. Chem. Phys. 18, 5799-5819. https://doi.org/10.5194/acp-18-5799-2018

Kroll, J.H., Ng, N.L., Murphy, S.M., Varutbangkul, V., Flagan, R.C., Seinfeld, J.H. (2005). Chamber studies of secondary organic aerosol growth by reactive uptake of simple carbonyl compounds. J. Geophys. Res. 110, D23207. https://doi.org/10.1029/2005JD006004

Kroll, J.H., Donahue, N.M., Jimenez, J.L., Kessler, S.H., Canagaratna, M.R., Wilson, K.R., Altieri, K.E., Mazzoleni, L.R., Wozniak, A.S., Bluhm, H., Mysak, E.R., Smith, J.D., Kolb, C.E., Worsnop, D.R. (2011). Carbon oxidation state as a metric for describing the chemistry of atmospheric organic aerosol. Nat. Chem. 3, 133-139. https://doi.org/10.1038/nchem.948

Kundu, S., Fisseha, R., Putman, A.L., Rahn, T.A., Mazzoleni, L.R. (2012). High molecular weight SOA formation during limonene ozonolysis: Insights from ultrahigh-resolution FT-ICR mass spectrometry characterization. Atmos. Chem. Phys. 12, 5523-5536. https://doi.org/10.5194/a cp-12-5523-2012

Kuwata, M., Chen, Q., Martin, S.T. (2011). Cloud condensation nuclei (CCN) activity and oxygento-carbon elemental ratios following thermodenuder treatment of organic particles grown by $\alpha$-pinene ozonolysis. Phys. Chem. Chem. Phys. 13, 14571-14583. https://doi.org/10.1039/c1c p20253g

Lambe, A.T., Onasch, T.B., Massoli, P., Croasdale, D.R., Wright, J.P., Ahern, A.T., Williams, L.R., Worsnop, D.R., Brune, W.H., Davidovits, P. (2011). Laboratory studies of the chemical composition and cloud condensation nuclei (CCN) activity of secondary organic aerosol (SOA) and oxidized primary organic aerosol (OPOA). Atmso. Chem. Phys. 11, 8913-8928. https://doi.org/10.5194/acp-11-8913-2011

Leungsakul, S., Jaoui, M., Kamens, R.M. (2005). Kinetic mechanism for predicting secondary organic aerosol formation from the reaction of d-limonene with ozone. Environ. Sci. Technol. 39, 9583-9594. https://doi.org/10.1021/es0492687

Liangou, A., Florou, K., Psichoudaki, M., Kostenidou, E., Tsiligiannis, E., Pandis, S.N. (2020). Development of a method for the measurement of the water solubility distribution of atmospheric organic aerosol. in prep

Louvaris, E.E., Karnezi, E., Kostenidou, E., Kaltsonoudis, C., Pandis, S.N. (2017). Estimation of the volatility distribution of organic aerosol combining thermodenuder and isothermal dilution measurements. Atmos. Meas. Tech. 10, 3909-3918. https://doi.org/10.5194/amt-10-39092017

Massoli, P., Lambe, A.T., Ahern, A.T., Williams, L.R., Ehn, M., Mikkilä, J., Canagaratna, M.R., Brune, W.H., Onasch, T.B., Jayne, J.T., Petäjä, T., Kulmala, M., Laaksonen, A., Kolb, C.E., Davidovits, P., Worsnop, D.R. (2010). Relationship between aerosol oxidation level and hygroscopic properties of laboratory generated secondary organic aerosol (SOA) particles. Geophys. Res. Lett. 37, L24801. https://doi.org/10.1029/2010GL045258

Meyer, N.K., Duplissy, J., Gysel, M., Metzger, A., Dommen, J., Weingartner, E., Alfarra, M.R., Prévôt, A.S.H., Fletcher, C., Good, N., McFiggans, G., Jonsson, Å.M., Hallquist, M., Baltensperger, U., Ristovski, Z.D. (2009). Analysis of the hygroscopic and volatile properties of ammonium sulphate seeded and unseeded SOA particles. Atmos. Chem. Phys. 9, 721-732. https://doi.org/10.5194/acp-9-721-2009

Moore, R.H., Nenes, A., Medina, J. (2010). Scanning mobility CCN analysis-A method for fast measurements of size-resolved CCN distributions and activation kinetics. Aerosol Sci. Technol. 44, 861-871. https://doi.org/10.1080/02786826.2010.498715 
Nakao, S. (2017). Why would apparent $\kappa$ linearly change with O/C? Assessing the role of volatility, solubility, and surface activity of organic aerosols. Aerosol Sci. Technol. 51, 1377-1388. https://doi.org/10.1080/02786826.2017.1352082

Petters, M.D., Kreidenweis, S.M. (2007). A single parameter representation of hygroscopic growth and cloud condensation nucleus activity. Atmos. Chem. Phys. 7, 1961-1971: https://doi.org/10.5194/acp-7-1961-2007

Poulain, L., Wu, Z., Petters, M.D., Wex, H. (2010). Towards closing the gap between hygroscopic growth and CCN activation for secondary organic aerosols - Part 3: Influence of the chemical composition on the hygroscopic properties of volatile fractions of aerosols. Atmos. Chem. Phys. 10, 3775-3785. https://doi.org/10.5194/acp-10-3775-2010

Reichert, M.D., Alvarez, N.J., Brooks, C.F., Grillet, A.M., Mondy, L.A., Anna, S.L., Walker, L.M. (2015). The importance of experimental design on measurement of dynamic interfacial tension and interfacial rheology in diffusion-limited surfactant systems. Colloid. Surface. A 467, 135142. https://doi.org/10.1016/j.colsurfa.2014.11.035

Rickards, A.M.J., Miles, R.E.H., Davies, J.F., Marshall, F.H., Reid, J.P. (2013). Measurements of the sensitivity of aerosol hygroscopicity and the $\kappa$ parameter to the $\mathrm{O} / \mathrm{C}$ ratio. J. Phys. Chem. 117, 14120-14131. https://doi.org/10.1021/jp407991n

Riipinen, I., Pierce, J.R., Donahue, N.M., Pandis, S.N. (2010). Equilibration time scales of organic aerosol inside thermodenuders: Evaporation kinetics versus thermodynamics. Atmos. Environ. 44, 597-607. https://doi.org/10.1016/j.atmosenv.2009.11.022

Rissanen, M.P., Kurtén, T., Sipilä, M., Thornton, J.A., Kangasluoma, J., Sarnela, N., Junninen, H., Jørgensen, S., Schallhart, S., Kajos, M.K., Taipale, R., Springer, M., Mentel, T.F., Ruuskanen, T., Petäjä, T., Worsnop, D.R., Kjaergaard, H.G., Ehn, M. (2014). The formation of highly oxidized multifunctional products in the ozonolysis of cyclohexene. J. Am. Chem. Soc. 136, 1559615606. https://doi.org/10.1021/ja507146s

Saathoff, H., Naumann, K.H., Möhler, O., Jonsson, Å.M., Hallquist, M., Kiendler-Scharr, A., Mentel, T.F., Tillmann, R., Schurath, U. (2009). Temperature dependence of yields of secondary organic aerosols from the ozonolysis of $\alpha$-pinene and limonene. Atmos. Chem. Phys. 9, 1551-1577. https://doi.org/10.5194/acp-9-1551-2009

Sareen, N., Schwier, A.N., Lathem, T.L., Nenes, A., McNeill, V.F. (2013). Surfactants from the gas phase may promote cloud droplet formation. Proc. Natl. Acad. Sci. 110, 2723-2728. https://doi.org/10.1073/pnas.1204838110

Tritscher, T., Dommen, J., Decarlo, P.F., Gysel, M., Barmet, P.B., Praplan, A.P., Weingartner, E., Prévôt, A.S.H., Riipinen, I., Donahue, N.M., Baltensperger, U. (2011). Volatility and hygroscopicity of aging secondary organic aerosol in a smog chamber. Atmos. Chem. Phys. 11, 11477-11496. https://doi.org/10.5194/acp-11-11477-2011

Varutbangkul, V., Brechtel, F.J., Bahreini, R., Ng, N.L., Keywood, M.D., Kroll, J.H., Flagan, R.C., Seinfeld, J.H., Goldstein, A.H. (2006). Hygroscopicity of secondary organic aerosols formed by oxidation of cycloalkenes, monoterpenes, sesquiterpenes, and related compounds. Atmos. Chem. Phys. 6, 2367-2388. https://doi.org/10.5194/acp-6-2367-2006

Warren, B., Malloy, Q.G.J., Yee, L.D., Cocker, D.R. (2009). Secondary organic aerosol formation from cyclohexene ozonolysis in the presence of water vapor and dissolved salts. Atmos. Environ. 43, 1789-1795. https://doi.org/10.1016/j.atmosenv.2008.12.026

Watne, Å.K., Westerlund, J., Hallquist, Å.M., Brune, W.H., Hallquist, M. (2017). Ozone and OHinduced oxidation of monoterpenes: Changes in the thermal properties of secondary organic aerosol (SOA). J. Aerosol Sci. 114, 31-41. https://doi.org/10.1016/j.jaerosci.2017.08.011

Witkowski, B., Gierczak, T. (2017). Characterization of the limonene oxidation products with liquid chromatography coupled to the tandem mass spectrometry. Atmos. Environ. 154, 297307. https://doi.org/10.1016/j.atmosenv.2017.02.005

Ye, Q., Wang, M., Hofbauer, V., Stolzenburg, D., Chen, D., Schervish, M., Vogel, A., Mauldin, R.L., Baalbaki, R., Brilke, S., Dada, L., Dias, A., Duplissy, J., El Haddad, I., Finkenzeller, H., Fischer, L., He, X., Kim, C., Kürten, A., Lamkaddam, H., ... Donahue, N.M. (2019). Molecular composition and volatility of nucleated particles from $\alpha$-pinene oxidation between $-50{ }^{\circ} \mathrm{C}$ and $+25{ }^{\circ} \mathrm{C}$. Environ. Sci. Technol. 53, 12357-12365. https://doi.org/10.1021/acs.est.9b03265

Yuan, C., Ma, Y., Diao, Y., Yao, L., Zhou, Y., Wang, X., Zheng, J. (2017). CCN activity of secondary aerosols from terpene ozonolysis under atmospheric relevant conditions. J. Geophys Res. 122, 
4654-4669. https://doi.org/10.1002/2016JD026039

Zhang, Q., Jimenez, J.L., Canagaratna, M.R., Allan, J.D., Coe, H., Ulbrich, I., Alfarra, M.R., Takami, A., Middlebrook, A.M., Sun, Y.L., Dzepina, K., Dunlea, E., Docherty, K., DeCarlo, P.F., Salcedo, D., Onasch, T., Jayne, J.T., Miyoshi, T., Shimono, A., Hatakeyama, S., ... Worsnop, D.R. (2007) Ubiquity and dominance of oxygenated species in organic aerosols in anthropogenicallyinfluenced Northern Hemisphere midlatitudes. Geophys. Res. Lett. 34, L13801. https://doi.org/10.1029/2007GL029979 